\title{
Hubungan Antara Kontrol Diri Dan Kecemasan Menghadapi Masa Pembebasan Pada Narapidana Di Lembaga Pemasyarakatan Wirogunan Yogyakarta
}

\author{
Laila Faried \\ Fuad Nashori \\ Fakultas Psikologi dan Ilmu Sosial Budaya, Universitas Islam Indonesia \\ Email: ay_laa@yahoo.co.id
}

\begin{abstract}
The purpose of this research was to understand the corelation between selfcontrols and the anxiety of the prisoner to face the liberation. The hypothesis of this research showed that there was negative corelation between self-control and the anxiety of the prisoner to face the liberation. The higher self-control the lower anxiety to face the liberation, so on the contrary, the lower self-control the higher the anxiety to face the liberation. The subjects of this research were men and women prisoners from correctional facility, who would be immediately liberated 5 to 6 months approaching the liberation. The scale which was used in this research was self-control scale, which was arranged by the researcher based on Averiil theory (1973) and anxiety based on Rosenhan and Seligman Theory (1989). The research's method to analyze the data was SPSS 17.0. This method was used to verify the negative corelation between self-control and anxiety of prisoners to face the liberation. Product moment correlation of Pearson showed the value of $r=-0,451$ and $p=0.007(p>0,01)$, which meant there was a significant negative correlation between self-control and anxiety of prisoners to face liberation.
\end{abstract}

Keywords: Self Control, Anxiety to facing the exemption

\section{Pendahuluan}

Dalam berbagai acara berita di televisi, hampir setiap hari selalu diperlihatkan beberapa berita mengenai tindak kriminalitas. Di Indonesia sendiri berdasarkan data pusat pengendalian dan operasi dari Markas Besar Polisi
Republik Indonesia (Mabes Polri) menunjukkan bahwa pada tahun 2011 kriminalitas mengalami peningkatan sebesar 6,3\% (Republika, 22/12). Kejahatan, khususnya kekerasan, paling banyak dilakukan oleh individu dengan kisaran usia antara 18-24 tahun 
dengan perbandingan laki-laki dan perempuan ialah 10:1 atau 20:1 (Kartono, 1995).

Kasus-kasus kriminalitas tersebut, dari kasus yang ringan hingga kasus yang berat, menyebabkan para pelaku harus menghadapi masalah hukum. Kasus-kasus tersebut terjadi karena desakan ekonomi, kekhilafan, mempertahankan diri, sampai alasan membela diri yang sering dikemukakan (Harsono, 1995). Meningkatnya kasus kriminalitas itu didasari sebagai bentuk kenakalan kejahatan yang melanggar hukum. Para pelaku tindakan kriminal yang tertangkap dan diproses secara hukum pidana yang kemudian disebut narapidana.

Narapidana yang menjalani pidana di lembaga pemasyarakatan (lapas), pada dasarnya telah kehilangan kebebasan untuk berinteraksi dengan masyarakat luar. Narapidana yang bersangkutan hanya dapat berinteraksi di dalam lapas saja. Kebebasan atau kemerdekaan berinteraksi telah hilang untuk jangka waktu tertentu, atau bahkan seumur hidup. Bahkan, pada kenyataannya bukan hanya kemerdekaan berinteraksi saja yang hilang, tetapi juga berbagai kemerdekaan yang lain ikut terampas (Harsono, 1995).

Dalam penjara, narapidana harus tidur dengan tempat yang tentunya tidak senyaman di rumah. Narapidana harus mengikuti aturan-aturan yang disertai dengan disiplin yang keras, bergaul dengan narapidana lain yang memiliki latar belakang yang berbeda serta harus menjalani hukuman yang diberikan bagi narapidana yang melanggar peraturan. Seorang narapidana dalam jangka waktu tertentu harus berada di dalam tempat yang dibatasi ruang lingkupnya, aktivitas yang terbatas, komunikasi terbatas, dan segala sesuatu yang terbatas. Adanya kondisi yang tidak menyenangkan dalam lapas tersebut dapat menimbulkan berbagai keadaan psikologis, seperti muncul perasaan tidak nyaman, gelisah, cemas serta tertekan (Harsono, 1995)

Kebebasan adalah masa yang paling ditunggu oleh narapidana yang menjalani hukuman. Narapidana akan merasakan kembali kehangatan dengan keluarga serta ruang gerak yang tidak terbatas setelah menjalani hukuman penjara (Triastuti, 2009). Namun, ada kekhawatiran mengenai bagaimana narapidana akan menjalani kehidupan usai bebas dari lapas. Apakah anggota keluarga bersedia menerima kembali atau apakah masyarakat bersedia menerima mereka sebagai anggota masyarakat seperti sebelum mereka menjadi narapidana menjadi semacam kekhawatiran karena sulitnya mendapatkan kepercayaan. Belum lagi ketika narapaida tersebut ingin mendapatkan lapangan pekerjaan usai bebas dari lapas (Ulyani, 2003).

Salah satu petugas lapas di Wirogunan menjelasakan bahwa memang ada perubahan secara psikologis terhadap narapidana yang akan bebas. 
Hubungan Antara Kontrol Diri dan Kecemasan..., Laila, Fuad

Hal ini terkait dengan persyaratanpersyaratan sebelum bebas serta adanya penerimaan dari masyarakat yang mungkin berbeda-beda. Ada masyarakat yang menerima, ada pula yang mengucilkan. Salah seorang narapidana juga menjelaskan bahwa memang merasa takut dikucilkan oleh keluarganya, sehingga takut bebas. Takut diperlakukan berbeda oleh keluarga serta takut tidak mendapatkan pekerjaan. Akibatnya merasa minder, tidak fokus dalam melakukan kegiatan, dan selalu mempunyai pemikiran negatif akan dijauhi oleh keluarga ataupun masyarakat.

Lembaga pemasyarakatan merupakan wadah pembinaan bagi narapidana berdasarkan sistem pemasyarakatan dengan upaya mewujudkan pemidanaan yang integratif. Pemidanaan yang integratif adalah upaya untuk membina dan mengembalikan narapidana ke dalam kesatuan hidup masyarakat yang baik dan berguna. Dengan kata lain, lembaga pemasyarakatan melaksanakan rehabilitasi, reduksasi, resosialisasi dan perlindungan baik terhadap narapidana dan masyarakat dalam pelaksanaan sistem pemasyarakatan. Bila tujuan pemidanaan adalah pemasyarakatan, seharusnya mantan narapidana tidak cemas lagi dan dapat diterima di masyarakat, hidup berdampingan dengan masyarakat dan tidak lagi diperlakukan secara diskriminatif oleh masyarakat.
Para narapidana yang akan memasuki masa asimilasi diketahui bahwa mereka memiliki reaksi cemas, perasaan gelisah, dan mudah tersinggung (Triastuti, 2009). Dijelaskan, kemungkinan hal tersebut disebabkan oleh masih negatifnya pandangan masyarakat terhadap seseorang yang keluar dari Lapas. Soetojo (Triastuti, 2009) berpendapat masih ada prasangka dan dugaan yang melekat bahwa orang lapas adalah orang yang selalu melakukan perbuatan negatif dan tercela sehingga masyarakat akan menolak dan menjauhi mereka. Penolakan tersebut menimbulkan kecemasan bagi para narapidana yang akan dibebaskan.

Kecemasan bisa dikendalikan dengan adanya kontrol diri pada diri seseorang. Kontrol diri berkaitan dengan bagaimana individu mengendalikan emosi serta dorongan-dorongan dari dalam dirinya (Hurlock, 1997). Menurut konsep ilmiah, pengendalian emosi berarti mengarahkan energi emosi ke saluran ekpresi yang bermanfaat dan dapat diterima secara sosial. Mengontrol emosi berarti mendekati suatu situasi dengan menggunakan sikap yang rasional untuk merespon situasi tersebut dan mencegah munculnya reaksi yang berlebihan.

Kemampuan mengontrol diri memungkinkan seseorang berperilaku lebih terarah dan dapat menyalurkan dorongan-dorongan dalam diri secara 
benar dan tidak menyimpang dari norma masyarakat. Kontrol diri difokuskan pada menguatkan diri secara positif, menghukum diri, memanipulasi kondisi emosi, memonitor diri sehingga mampu mengontrol kecemasan, yang terdiri dari sulit konsentrasi, tidak percaya pada kemampuan diri, sering memikirkan bahaya, gelisah dan khawatir (Imam, 2007).

Berdasarkan penjelasan latar belakang di atas, maka rumusan penelitian ini adalah apakah ada hubungan antara kontrol diri dengan kecemasan menghadapi masa pembebasan pada narapidana di lembaga permasyarakatan? Adapun tujuan penelitian ini adalah untuk mengetahui kontrol diri narapidana dalam menghadapi kecemasan saat menghadapi masa pembebasan di lembaga pemasyarakatan.

\section{Tinjauan Pustaka}

\section{Kecemasan Menghadapi Masa pembebasan}

Kecemasan menghadapi masa pembebasan adalah perasaan tidak aman dan kekawatiran yang timbul karena merasa akan terjadi sesuatu yang tidak menyenangkan dengan sumber yang sebagaian sebagian besar tidak diketahui, berasal dari dalam diri individu, perasaan-perasaan atau pikiran-pikiran yang tidak menyenangkan mengenai harapan di masa datang setelah narapidana bebas menjalani hukuman (Daradjat, 1990).

Daradjat (1990) menyatakan bahwa kecemasan memiliki segi yang di luar kesadaran dan tidak jelas, seperti takut tanpa mengetahui sebabnya dan tidak bisa menghindari perasaan yang tidak menyenangkan. Kecemasan muncul karena beberapa situasi yang mengancam diri manusia sebagai makhluk sosial. Timbulnya kecemasan pada narapidana yang akan menghadapi masa pembebasan adalah karena merasakan adanya situasi yang mengancam. Kecemasan menghadapi masa pembebasan adalah perasaan khawatir, gelisah, tegang, dan perasaan-perasaan lain yang kurang menyenangkan karena narapidana merasa takut menghadapi masyarakat luar. Kecemasan menghadapi masa depan dialami oleh narapidana disebabkan oleh kondisi masa datang yang belum jelas dan belum teramalkan.

\section{Aspek-aspek Kecemasan}

Menurut Daradjat (1990), aspekaspek kecemasan terbagi menjadi dua bentuk, yaitu: a) fisiologis: bentuk reaksi fisiologis berupa detak jantung meningkat, pencernaan tidak teratur, keringat berlebihan, ujung-ujung jari terasa dingin, sering buang air kecil, tidur tidak nyenyak, kepala pusing, nafsu makan hilang dan sesak nafas; b) psikologis: yang terbagi menjadi dua bentuk, yaitu: 
Hubungan Antara Kontrol Diri dan Kecemasan..., Laila, Fuad

\section{Aspek kognitif}

Termasuk dalam aspek ini adalah tidak mampu memusatkan perhatian

\section{Aspek afektif}

Termasuk dalam aspek ini antara lain : takut, merasa dirinya akan ditimpa bahaya.

Aspek-aspek lain menurut Rosenhan dan Seligman (1989) meliputi: a) somatic, yaitu reaksi tubuh terhadap bahaya; b) kognitif, yaitu respon terhadap kecemasan dalam pikiran manusia; c) emosi, yaitu perasaan manusia yang mengakibatkan individu secara teru-menerus khawatir, merasa takut terhadap bahaya yang mengancam; dan d) perilaku, yaitu reaksi dalam bentuk perilaku manusia terhadap ancaman dengan menghindar atau menyerang.

Dalam penelitian ini, kecemasan dalam menghadapi masa pembebasan pada narapidana adalah kecemasan yang belum terwujud, hanya ada rasa khawatir yang berlebihan. Kecemasan terjadi adanya pemikiran yang mendukung untuk terus-merasa khawatir sesuai dengan aspek-aspek kecemasan menurut Rosenhan dan Seligman (1989).

Faktor-faktor Yang Memengaruhi Kecemasan

Menurut Nevid, Rathus, dan Greene (2005) kecemasan dipengaruhi beberapa faktor, yaitu:

a. Faktor sosial lingkungan, meliputi pemaparan terhadap peristiwa yang mengancam atau traumatis, mengamati respon takut pada orang lain, dan kurangnya dukungan sosial.

b. Faktor biologis, meliputi predisposisi genetis, ireguaritas dalam fungsi neurotransmiter, dan abnormalitas dalam jalur otak yang memberi sinyal bahaya atau yang menghambat tingkah laku repetitif.

c.Faktor perilaku, meliputi pemasangan stimuli aversif dan stimuli yang sebelumnya netral, kelegaan dari kecemasan karena melakukan ritual kompulsif atau menghindari stimuli fobik, dan kurangnya kesempatan untuk pemunahan karena penghindaran terhadap objek atau situasi yang ditakuti.

d. Faktor kognitif dan emosional, meliputi konflik psikologis yang tidak terselesaikan (Freudian atau teori Psikodinamika) faktor-faktor kognitif seperti prediksi berlebihan tentang ketakutan, keyakinan-keyakinan yang self defeating atau irasional, sensivitas berlebih terhadap ancaman, sensivitas kecemasan, salah atribusi dari sinyal tubuh, dan self efficacy yang rendah.

Kecemasan sering terjadi ketika seseorang dihadapkan dalam situasi yang tidak semestinya. Kecemasan bisa terjadi kArena faktor sosial, faktor perilaku dan bahkan faktor kognitifnya. Dalam penelitian ini kecemasan menghadapi masa pembebasan narapidana terjadi karena adanya faktor sosial lingkungan dan faktor kognitif emosional. 
Faktor sosial, narapidana takut ketika bebas nanti tidak mendapatkan dukungan dari keluarga dan juga lingkungannya, sehingga mengakibatkan ketakutan yang berlebihan terhadap sesuatu hal yang belum pasti terjadi. Dalam faktor kognitif dan emosional adanya prediksi yang berlebihan tentang ketakutan serta sensitivitas berlebih terhadap ancaman. Hal ini terjdi ketika narapidana di hadapkan pada masa pembebasan, mempunyai prediksi yang berlebihan tentang ketakutanya dalam menghadapi masyarakat luar nantinya setelah bebas.

\section{Pengertian Kontrol Diri}

Kontrol diri berkaitan dengan bagaimana individu mengendalikan emosi serta dorongan-dorongan dalam dirinya, (Hurlock, 1997). Kazdin (Jannah \& Rahayu, 2007) mengungkapkan kontrol diri diperlukan guna membantu individu dalam mengatasi kemampuan yang terbatas dan membantu mengatasi berbagai hal merugikan yang dimungkinkan berasal dari luar. Menurut Chaplin (2001) kontrol diri adalah kemampuan untuk membimbing tingkah laku sendiri dalam artian kemampuan seseorang untuk menekan atau merintangi impuls-impuls atau tingkah laku impulsif. Kontrol diri menyangkut seberapa kuat seseorang memegang nilai dan kepercayaan untuk dijadikan acuan ketika bertindak atau mengambil suatu keputusan.
Lazarus (1976) mengatakan bahwa kontrol diri menggambarkan keputusan individu yang melalui pertimbangan kognitifnya untuk menyatakan perilaku yang telah disusun guna meningkatkan hasil dan tujuan tertentu seperti apa yang dikehendaki. Hal ini berarti kontrol diri mampu memahami keseluruhan pengungkapan diri baik yang positif maupun negatif sehingga individu mampu menyadari apa yang bisa membangkitkan ekspresi-ekspresi positif maupun negatif di dalam dirinya. Dengan demikian, kontrol diri merupakan suatu kecakapan individu dalam kepekaan membaca situasi diri dan lingkungan serta kemampuan untuk mengontrol dan mengelola faktorfaktor perilaku sesuai dengan situasi dan kondisi untuk menampilkan diri dalam melakukan sosialisasi pada lingkungan.

\section{Aspek- aspek Kontrol diri}

Averill (1973) berpendapat terdapat tiga jenis kontrol diri yang meliputi lima aspek, yaitu: kontrol perilaku (behavioral control), mengontrol kognisi (cognitive control), dan mengontrol keputusan (decisional control).

1. Kontrol perilaku (behavioral Control) adalah kemampuan untuk memodifikasi suatu keadaan yang tidak menyenangkan, kemampuan ini terdiri dari:

a) Kemampuan mengontrol perilaku untuk menentukan siapa yang mengendalikan situasi. 
Hubungan Antara Kontrol Diri dan Kecemasan..., Laila, Fuad

b) Kemampuan mengontrol stimulus untuk menghadapi stimulus yang tidak diinginkan dengan cara mencegah atau menjauhi stimulus.

2. Kontrol kognitif (cognitive control) yaitu kemampuan individu untuk mengolah informasi yang tidak diinginkan dengan cara menginterpretasikan, menilai, atau memadukan suatu kejadian dalam suatu kerangka kognitif sebagai adaptasi psikologis atau untuk mengurangi tekanan. Kemampuan ini meliputi:
a)Kemampuan mengantisipasi peris- tiwa atau keadaan melalui berbagai pertimbangan secara relatif-objektif dengan didukung oleh informasi yang dimilikinya.
b) Kemampuan menafsirkan peristiwa atau keadaan dengan cara mem- perhatikan segi-segi positif secara subjektif.

3. Kontrol dalam mengambil keputusan (decisional control) adalah kemampuan untuk memilih suatu tindakan berdasarkan sesuatu yang diyakini atau disetujui. Kontrol pribadi dalam menentukan pilihan akan berfungsi baik dengan adanya kesempatan, kebebasan atau kemungkinan pada diri individu untuk memilih beberapa hal yang sama memberatkan.

Hubungan Kontrol Diri dengan Kecemasan Menghadapi Masa Pembebasan
Kontrol diri sangat berpengaruh terhadap kecemasan dalam menghadpi masa pembebasan pada narapidana. Narapidana takut ketika dihadapkan dalam lingkungan luar yang baru setelah mereka berada dalam lapas. Takut akan adanya penolakan dari keluarga ataupun masyarakat. Masa pembebasan adalah suatu masa seorang narapidana kembali ke masyarakat dengan sesungguhnya karena telah selesai menjalani masa pidana. Setelah selesai menjalani masa pidana, narapidana mengalami kecemasan, terutama bagi narapidana yang belum menentukan masa depannya. Perasaan gelisah, terjadi pertentangan batin antara ingin keluar dan takut keluar, menjadi sederet perasaan yang menghantui. Keinginan keluar dan berkumpul dengan sanak keluarga, mendorong narapidana untuk ingin segera bebas, tetapi semakin dekat dengan masa pembebasan, semakin besar rasa takut yang dialami narapidana hingga akibatnya merasa gelisah, sulit untuk tidur, tidak enak makan, dan sering mengigau ketakutan (Kartono, 1981).

Menjelang masa pembebasan, menimbulkan kecemasan pada narapidana sehingga perlu adanya kontrol diri pada narapidana untuk mengatasi kecemasan. Pada aspek kontrol diri yang dikemukakan oleh Averill (1973), kontrol diri mampu memengaruhi individu dalam mengontrol perilakunya sehingga tidak 
menimbulkan efek yang negatif. Dalam hal ini kontrol diri berkaitan dengan bagaimana individu mengendalikan emosi serta dorongan-dorongan dalam dirinya, (Hurlock, 1997). Lazarus (1976) mengatakan bahwa kontrol diri menggambarkan keputusan individu melalui pertimbangan kognitif untuk menyatakan perilaku yang telah disusun guna meningkatkan hasil dan tujuan tertentu seperti apa yang dikehendaki. Hal ini berarti kontrol diri mampu memahami keseluruhan pengungkapan diri baik yang positif maupun negatif sehingga individu menyadari apa yang bisa membangkitkan ekspresi-ekspresi positif maupun negatif di dalam dirinya.

Kontrol diri merupakan Kemampuan individu untuk mengendalikan tindakan yang ditandai dengan kemampuan dalam merencanakan hidup. Kecemasan menghadapi masa bebas oleh narapidana merupakan emosi yang berlebihan karena muncul rasa takut dan rasa khawatir yang belum pasti akan terjadi. Dalam hal ini, kontrol diri memengaruhi kecemasan menghadapi masa pembebasan pada narapidana. Kontrol diri difokuskan pada menguatkan diri secara positif, menghukum diri, memanipulasi kondisi emosi, memonitor diri sehingga mampu mengontrol kecemasan, yang sering memikirkan bahaya, merasa gelisah dan khawatir (Imam, 2007). Adanya kontrol diri dalam mengendalikan perilaku cemas, serta merubah pola pikir yang tidak realistis menjadi pemikiran yang positif, sehingga hipotesis yang diajukan dalam penelitian ini adalah ada hubungan negatif antara kontrol diri dengan kecemasan narapidana dalam menghadapi masa pembebasan. Jika kontrol diri tinggi maka kecemasan menghadapi masa pembebasan rendah, begitu juga sebaliknya, jika kontrol diri rendah maka kecemasan menghadapi masa pembebasan tinggi.

\section{Metode Penelitian}

\section{Subjek Penelitian}

Subjek dalam penelitian ini adalah para narapidana di Lembaga Permasyarakatan Wirogunan, Yogyakarta, yang akan bebas dengan rentang waktu 5 sampai 6 bulan menjelang pembebasan. Subjek berjenis kelamin laki-laki atau perempuan.

\section{Metode Pengumpulan Data}

Metode pengumpulan data pada penelitian ini menggunakan metode kuantitatif, yaitu menggunakan alat ukur skala yang disusun sendiri oleh peneliti berdasarkan teori kontrol diri dari Averill (1973) dan kecemasan dari Daradjat (1990). Sementara teknik pengambilan data dilakukan dengan menggunakan teknik purposive sampling yaitu dengan cara memberikan skala pada subjek yang memiliki karakteristik tertentu.

\section{Metode Analisis Data}


Hubungan Antara Kontrol Diri dan Kecemasan..., Laila, Fuad

Peneliti menggunakan analisis statistik untuk metode analisis data, yaitu uji korelasi product momen dari Pearson. Teknik Kolerasi ini digunakan untuk mengetahui ada tidaknya hubungan antara kontrol diri dengan kecemasan menghadapi masa pembebasan narapidana di lembaga pemasyarakatan. Sementara pengolahan data dilakukan dengan mengunakan program SPSS 16 for Windows.

\section{Hasil Penelitian dan Pembahasan}

\section{Uji Normalitas}

Uji normalitas menggunakan teknik One-Sample Kolmogorov-Smirnovdari menunjukkan K-SZ sebesar 0,722 dengan nilai $p=0,674(p>0,05)$ untuk kecemasan dan K-SZ sebesar 1,053 dengan nilai $p=0,218(p>0,05)$ untuk kontrol diri. Hasil uji normalitas ini menunjukkan bahwa sebaran data terdistribusikan dengan normal.

\section{Uji Linieritas}

Uji Linieritas menggunakan teknik Compare Means menunjukkan $\mathrm{F}$ linierity $=10,525$ dan $p=0,05$. Hasil menunjukkan bahwa hubungan antara variable kontrol dan kecemasan menghadapai masa pembebasan adalah linear dengan $p<0,05$, sehingga dapat dikatakan data linear.

\section{Uji Hipotesis}

Uji hipotesis menggunakan analisis statistik Product Moment dari Pearson menunjukkan korelasi antara variable kontrol diri dan kecemasan menghadapi masa pembebasan adalah $r=$ " 0,451 dengan $p=0,007(p>0,01)$. Hal ini berarti bahwa ada hubungan negatif yang signifikan antara kontrol diri dan kecemasan menghadapi masa pembebasan pada narapidana sehingga hipotesis yang di ajukan adalah diterima.

\section{Pembahasan}

Penelitian ini dimaksudkan untuk mencari hubungan antara kontrol diri dan kecemasan menghadapi masa pembebasan narapidana di lembaga pemasyarakatan Wirogunan, Yogyakarta. Berdasarkan analisis statistik yang telah dilakukan menggunakan teknik korelasi Product Moment dari Pearson menunjukkan bahwa koefisien korelasi antara variabel kontrol diri dan kecemasan menghadapi masa pembebasan adalah sebesar $-0,451$ dengan $p=0,007(p>0,01)$. Hasil statistik ini berarti bahwa hipotesis yang diajukan peneliti terbukti karena nilai $p$ $<$ dari 0,05. Dengan kata lain, kontrol diri memiliki korelasi secara negatif dengan kecemasan menghadapi masa pembebasan.

Hasil uji statistik di atas dapat dikatakan bahwa kontrol diri memengaruhi seorang narapidana dalam mengatasi tingginya kecemasan. Tingginya kecemasan dalam menghadapi masa pembebasan sesuai dengan penelitian Triastuti (2009) bahwa memang ada 
kecemasan saat narapidana dihadapkan pada masa pembebasan. Adanya kecemasan yang terjadi pada narapidana dipengaruhi oleh kontrol diri pada diri narpidana tersebut. Jika kontrol diri pada narapidana rendah, maka menimbulkan rasa cemas pada narapidana yang akan menjalani masa pembebasan.

Kontrol diri berkaitan dengan kemampuan individu mengendalikan emosi serta dorongan-dorongan di dalam diri (Hurlock, 1997). Kontrol diri juga merupakan perasaan seseorang yang dapat membuat keputusan dan mengambil tindakan yang efektif untuk menghasilkan akibat yang diinginkan dan menghindari akibat yang tidak diinginkan. Kontrol diri merupakan suatu kecakapan individu dalam kepekaan membaca situasi diri dan lingkungannya serta kemampuan untuk mengontrol dan mengelola faktor-faktor perilaku sesuai dengan situasi dan kondisi untuk menampilkan diri dalam melakukan sosialisasi pada lingkungan maupun pada diri sendiri.

Kartono (1981) menjelaskan bahwa masa pembebasan adalah suatu masa seorang narapidana kembali ke masyarakat dengan sesungguhnya karena telah selesai menjalani masa pidana. Setelah selesai menjalani masa pidana, narapidana mengalami kecemasan, terutama bagi narapidana yang belum menentukan masa depannya. Sedangkan Daradjat (1990) menyatakan bahwa kecemasan juga memiliki segi yang di luar kesadaran dan tidak jelas, seperti takut tanpa mengetahui sebabnya dan tidak bisa menghindari perasaan yang tidak menyenangkan tersebut. Kecemasan muncul karena beberapa situasi yang mengancam diri manusia sebagai makhluk sosial. Timbulnya kecemasan pada narapidana yang akan menghadapi masa pembebasan adalah karena merasakan adanya situasi yang megancam.

Penelitian ini menunjukkan bahwa kontrol diri memengaruhi tingkat kecemasan seseorang. Dapat dilihat dari aspek kecemasan bahwa ada reaksi kognitif (perasaan tegang, gelisah, perasaan takut), reaksi somatik (tidak bisa tidur, dan detak jantung meningkat, sering kebelakang), reaksi emosi (mudah marah dan akan terjadi sesuatu hal yang berbahaya dan juga pemikiran yang selalu takut terjadi hal-hal yang buruk) dan pada rekasi perilaku yang ditunjukkan dnegan perilaku menyendiri dan tidak ingin diganggu. Berdasarkan Aspek-aspek kontrol diri yang dikemukakan Averill (1973), kecemasan dipengaruhi oleh adanya kontrol diri, salah satunya pada aspek kemampuan kontrol kognisi, di mana individu mampu mengalihkan pemikiran dengan berfikir yang realistis, berfikir positif, serta kemampuan kontrol keputusan yaitu memutuskan sesuatu tindakan yang diyakini baik dan tidak merugikan orang lain.

Menurut Hurlock (1997) secara garis besar faktor yang memengaruhi 
Hubungan Antara Kontrol Diri dan Kecemasan..., Laila, Fuad

kontrol diri terdiri dari faktor eksternal dan internal. Faktor eksternal salah satunya terdapat dalam keluarga terutama orangtua. Orang tua akan menentukan bagaimana kemampuan mengontrol diri seseorang. Pola asuh orangtua dalam menerapkan sikap disiplin sejak dini secara intens kepada anak akan diinternalisasi oleh anak dan akan menjadi kontrol diri bagi anak di masa mendatang. Orangtua dalam hal ini menempati posisi penting dan sangat menentukan pembentukan kepribadian anak. Baik buruknya anak ditentukan oleh cara atau perilaku orangtua. Sementara, faktor internal yang ikut turut andil dalam kemampuan mengontrol diri adalah usia. Semakin bertambah usia seseorang maka semakin baik kemampuan kontrol diri anak.

Kecemasan sering kali terjadi ketika seseorang dihadapkan dalam situasi yang tidak semestinya. Kecemasan bisa terjadi kerena faktor sosial, faktor perilaku bahkan faktor kognitifnya. Dalam penelitian ini, kecemasan menghadapi masa pembebasan narapidana terjadi karena adanya faktor sosial lingkungan dan faktor kognitif emosional. Faktor sosial, karena narapidana takut setelah bebas tidak mendapatkan dukungan dari keluarga dan juga lingkungannya, sehingga mengakibatkan ketakutan yang berlebihan terhadap suatu kondisi yang belum pasti terjadi.

Menurut Greenbreg (Triastuti, 2009) dalam menghadapi kecemasan diperlukan cara untuk meminimalisasi perasaaan, bagaimana individu berupaya mengatasi masalah atau menangani emosi yang muncul yang umumnya bersifat negatif. Adanya kontrol diri dalam mengendalikan perilaku cemas, serta merubah pola pikir yang tidak realistis tersebut menjadi pemikiran yang positif, sehingga ada hubungan antara kontrol diri dan kecemasan menghadapi masa pembebasan.

Pada penelitian ini masih ada beberapa kelemahan, seperti penelitian hanya dilakukan pada satu tempat saja dengan subjek yang terbatas, sehingga belum mewakili sepenuhnya bahwa kontrol diri dapat memengaruhi kecemasan dalam menghadapi masa pembebasan pada narapidana.

\section{Simpulan dan Saran}

\section{Simpulan}

Berdasarkan hasil penelitian, dapat disimpulkan bahwa ada hubungan negatif yang signifikan antara kontrol diri dan kecemasan menghadapi masa pembebasan pada narapidana. Semakin tinggi kontrol diri, semakin rendah kecemasan menghadapi masa pembebasan, begitu juga sebaliknya semakin rendah kontrol diri maka semakin tinggi kecemasan yang dialami narapidana. Dengan demikian, hipotesis yang diajukan oleh peneliti dapat diterima. 


\section{Saran}

Bagi subjek penelitian (narapidana): diharapkan lebih percaya diri di tengahtengah masyarakat dengan cara kontrol diri yang baik untuk mengatasi kecemasan saat menjelang masa pembebasan. Sementara saran bagi pihak lapas, hendaknya dapat memberikan bimbingan dan pelatihan yang bermanfaat bagi narapidana agar nantinya setelah keluar dari lapas mereka bisa diterima kembali oleh masyarakat dan menjadi manusiamanusia yang berguna bagi masyarakat.

Bagi peneliti selanjutnya diharapkan mampu untuk lebih mengembangkan variabel penelitian sejenis, baik dari segi tema dan teori yang digunakan. Teori hendaknya yang terbaru dan aspek yang digunakan hendaknya lebih relevan agar penelitian selanjutnya menjadi lebih baik dan lebih berkualitas.

\section{Daftar Pustaka}

Averill. J.R.. 1973. Personal Control Over Aversive Stimuli and Its Relationship to Stress. Psychological Bulletin, 80 (4), 286-303.

Chaplin, J. P. 2001. Kamus Lengkap Psikologi. Jakarta: Rajawali Press. Triastuti, D., Sutikno, N., \& Risnawaty, W. 2009. Gambaran Kecemasan dan Strategi Penanganan Anak Didik Kasus Pembunuhan: Studi Kasus Andik yang Telah Memasuki Masa Asimilasi di Lapas Anak Pria Tangerang. Jurnal Arkhe Universi- tas Tarumanegara, 1, 31-39.

Daradjat, Z. 1990. Kesehatan Mental. Jakarta: Gunung Agung.

Hurlock, EB. 1997. Psikologi Perkembangan: Suatu Pendekatan Sepanjang Rentang Kehidupan. Alih Bahasa Istiwidayanti. Jakarta: Penerbit Erlangga.

Harsono, C.I. 1995. Sistem Baru

Pembinaan Narapidana. Jakarta:

Djambatan.

Kartono, K. 1995. Patologi Sosial Jilid

1. Jakarta: PT. Raja Grafindo Persada.

Kartono, K. 1981. Gangguan-gangguan

Psikis. Bandung. Sinar Baru.

Lazarus, R.S. 1976. Pattern of Adjustment. Tokyo: Mc Graw-Hill Kogakhusu Inc.

Jannah, M \& Rahayu, S, 2007. Perilaku Penunda Kepuasan Ditinjau dari Kontrol Diri dan Inteligensi Pada Anak Usia Sekolah. Jurnal Pendidikan Dasar, 18 (1), 8-14.

Nevid, J. S., Rathus, S. A., \& Greene, B. 2005. Psikologi Abnormal Edisi Kelima Jilid 1. Jakarta: Erlangga. Rosenhan, D. L \& Seligman, E.P. 1989. Abnormal Psychology, $2^{\text {th }}$ Edition. New York: W.W. Norton \& Company Inc.

Ulyani, F . 2003 Hubungan Antara Menghadapi Masa Pembebasan dan Lamanya Masa Pidana dengan Kepercayaan Diri Narapidana. Skripsi (Tidak Diterbitkan). Yogyakarta: Fakultas Psikologi Universitas Islam Indonesia 